\title{
Proefschrift
}

\section{Career preference of medical students and career choice of recent graduates. Factors influencing the preference for a choice of a medical specialty in general and in public health in particular.}

Soethout MBM. Career preference of medical students and career choice of recent graduates. Factors influencing the preference for a choice of a medical specialty in general and in public health in particular.VU, Amsterdam, 21 december 2007. Promotoren: prof. dr. G. van der Wal en prof. dr. Th.J. ten Cate. 164 pagina's. ISBN 9789064641831

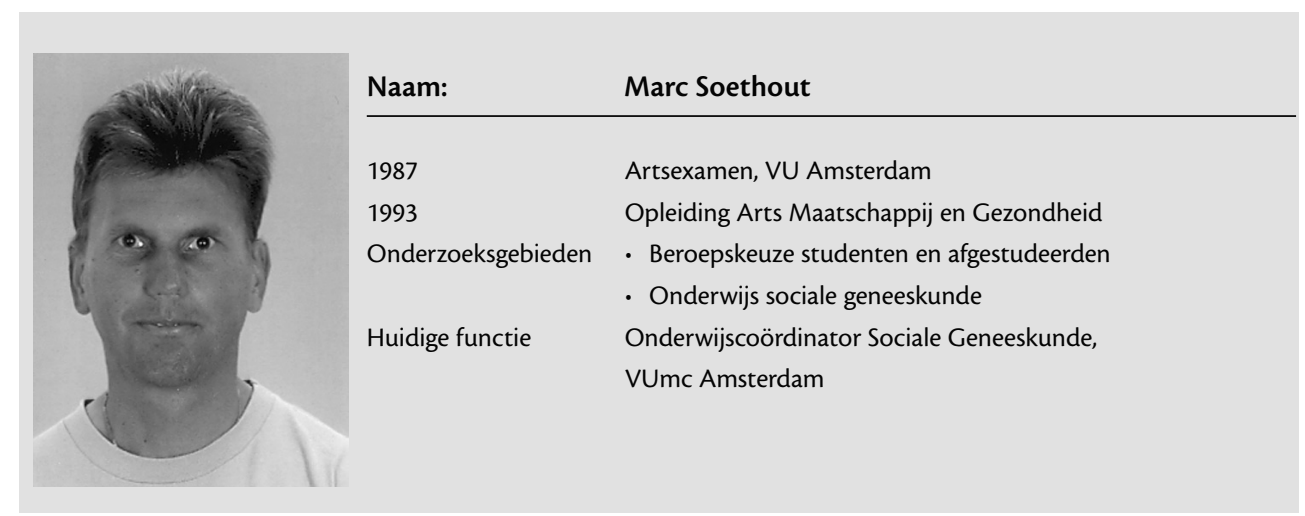

\section{Inleiding}

Basisartsen die recent zijn afgestudeerd werken meestal enkele jaren voordat zij hun vervolgopleiding starten. Hun uiteindelijke beroepskeuze wordt dus enkele jaren uitgesteld. Tegenwoordig wordt een nauwere aansluiting tussen de initiële en medische vervolgopleiding nagestreefd, zodat afgestudeerden gedwongen zullen worden hun uiteindelijke beroepskeuze eerder te maken. Er zijn echter relatief weinig gegevens bekend over de factoren die meespelen bij de beroepskeuze van geneeskunde studenten en recent afgestudeerden in Nederland en over de wijze waarop faculteiten hun loopbaanadvies voor studenten kunnen verbeteren.

\section{Vraagstellingen}

Het doel van de studies in dit proefschrift was meer inzicht te verkrijgen in de factoren die meespelen bij de beroepskeuze van geneeskunde studenten en recent afgestudeerde basisartsen in Nederland, en in het bijzonder die factoren die een rol spelen gedurende de opleiding en beïnvloed kunnen worden door de faculteiten of het beroepsveld. Hierbij werd gefocust op studentkenmerken, op perceptie van kenmerken van het toekomstig medisch beroep, op kenmerken van het beroep die gerelateerd zijn aan de beroepspreferentie en op de beroepskeuze van zowel studenten als recent afgestudeerden. We waren vooral geïnteresseerd in de factoren die meespeel- 
den bij de beroepskeuze voor de sociale geneeskunde, omdat slechts weinig afgestudeerden direct na het afstuderen in dit vakgebied werkzaam zijn en niet bekend is of deze lage preferentie al tijdens de basisopleiding begint.

\section{Methode}

Allereerst werd een literatuuronderzoek verricht, gericht op het identificeren van factoren die geassocieerd zijn met de beroepskeuze voor een medische specialisatie van recent afgestudeerde artsen in Europa. Mede op grond van deze resultaten is een vragenlijst ontwikkeld over de beroepskeuze en de hieraan gerelateerde factoren. Voor 37 specialismen werd geïnventariseerd hoe graag men dit later wilde worden en hoe goed de kennis was van deze beroepen. Ook zijn vragen toegevoegd over biografische kenmerken, zoals scholing van de ouders en eigen ervaringen in de gezondheidszorg. Tenslotte werd gevraagd naar de aantrekkelijkheid van diverse aspecten van het medisch beroep en in hoeverre deze aspecten van toepassing waren op een viertal medische disciplines (chirurgie, huisartsgeneeskunde, interne geneeskunde en psychiatrie). De vragenlijst is voorgelegd aan geneeskunde studenten van het VUmc Amsterdam en het UMC Utrecht $(n=2928)$ en aan recent afgestudeerden van beide medische centra $(n=1091)$. De afgestudeerden ontvingen dezelfde vragenlijst maar hen werd retrospectief gevraagd naar hun beroepsvoorkeur ten tijde van afstuderen. Ook werd gevraagd naar de werkplek van hun huidig functioneren en welke factoren hierop van invloed waren geweest. Een jaar laten ontvingen alle VUmc studenten en afgestudeerden van beide medische centra wederom eenzelfde vragenlijst.

Voor de analyse werd de studiepopulatie ingedeeld in diverse studentengroepen en afgestudeerden en sommige specialismen werden in meer detail geanalyseerd met een specifieke focus op de sociaal geneeskundige beroepen.

\section{Resultaten}

Het literatuuronderzoek liet zien dat enthousiasme, eigen vaardigheden, interesse in de mens en gezinsomstandigheden de belangrijkste factoren waren bij de beroepskeuze voor een medische specialisatie. Voor vrouwelijke artsen waren vooral adequate werktijden en parttime werkmogelijkheden van belang. Ons onderzoek liet zien dat deze factoren ook een rol speelden bij recent afgestudeerden in Nederland. Hoewel dit wel afhankelijk was van het soort specialisme en de mogelijkheden voor parttime werk was dit voor zowel mannen als vrouwen belangrijk. Vooral de keuze voor huisartsgeneeskunde was sterk geassocieerd met de medische achtergrond van ouders en met het vrouwelijk geslacht. De algemene aantrekkelijkheid van het medisch beroep werd niet beïnvloed door ervaringen in de coschappen. Verder hadden studenten weinig belangstelling voor de sociale geneeskunde en daalde de voorkeur voor het beroep van jeugdarts gedurende de artsopleiding. Tenslotte bleek het beroepsbeeld van de jeugdarts te verschillen van dat van praktiserende jeugdartsen. De juistheid van hun perceptie van het beroep werd nauwelijks beïnvloed door hun voorkeur voor dit beroep en ook niet door de aan hen gerapporteerde kennis van het beroep of ervaring in het coschap jeugdgezondheidszorg.

\section{Conclusie en discussie}

Ons onderzoek laat zien dat diverse factoren een rol spelen bij de beroepskeuze van medisch studenten en recent afgestudeerde artsen. Studentkenmerken, kenmerken van het specialisme en de aantrekkelijkheid van het beroep beïnvloeden 
de beroepskeuze van geneeskunde studenten. Volgens studenten en afgestudeerden is de mogelijkheid van parttime werk nog steeds een belangrijke factor in de beroepskeuze voor een medische specialisatie. Dit zal in de komende jaren wellicht ook invloed hebben op de beroepskrachtenplanning van diverse specialismen in Nederland.

De preferentie voor een sociaal geneeskundig beroep is laag gedurende de basisopleiding en in het bijzonder de preferentie voor het beroep van jeugdarts daalt sterk gedurende de opleiding. Om het aantal studenten dat kiest voor sociale geneeskunde, en in het bijzonder voor de jeugd- gezondheidszorg, te doen toenemen zal meer aandacht besteed moeten worden aan de attractiviteit van het beroep en aan de dagelijkse praktijk van dit vak.

Een adequate beroepskeuze, hetgeen een goed beroepsadvies inhoudt op een vroeg moment gedurende de opleiding die al start gedurende de basisartsopleiding, is gebaat bij een nauwe aansluiting tussen de initiële en de vervolgopleiding.

Tenslotte is adequate monitoring van studenten en afgestudeerden in relatie tot beroepskeuze noodzakelijk voor een goede beroepskrachtenplanning en beroepsadvies. Regelmatig longitudinaal onderzoek wordt daarom aanbevolen. 